\title{
Dendrimer-Based Transient Supramolecular Networks
}

Ron M. Versteegen, D.J.M. van Beek, Rint P. Sijbesma,

Dimitris Vlassopoulos, George Fytas, and E.W. Meijer

Laboratory of Macromolecular and Organic Chemistry, Eindhoven University of Technology, P.O. Box 513, 5600 MB Eindhoven, The Netherlands

\section{Supporting Information}

General methods and instrumentation. NMR spectra were recorded on a Varian Inova $500 \mathrm{MHz}$ spectrometer, a Varian Inova $400 \mathrm{MHz}$ spectrometer, and a Varian Gemini $300 \mathrm{MHz}$ spectrometer. Infrared spectra were measured on a Perkin Elmer 1600 FT-IR. MALDI-TOF spectra were obtained at a Perseptive Biosystems Voyager DE-Pro MALDI-TOF mass spectrometer (accelerating voltage: 20kV; grid voltage: $74.0 \%$, guide wire voltage: $0.030 \%$, delay: $200 \mathrm{~ms}$, low mass gate $900 \mathrm{amu}$ ). Samples for MALDI-TOF were prepared by adding a solution of the polymers in THF $(20 \mu \mathrm{l}, \mathrm{c}=1 \mathrm{mg} / \mathrm{ml})$ to a solution of $\alpha$-cyano-4-hydroxycinnamic acid in THF $(10 \mu \mathrm{l}, \mathrm{c}=20 \mathrm{mg} / \mathrm{ml})$ and subsequent thoroughly mixing. This mixture $(0.3 \mu \mathrm{l})$ was brought on a sample plate, and the solvent was evaporated.

Materials. Borane-tetrahydrofuran complex (1 $\mathrm{M}$ in THF), sodium hydride $(60 \%$ dispersion in mineral oil), tetrabutylammonium hydrogensulfate, 15-crown-5, and ethyl isocyanatoacetate were purchased from Aldrich; benzyl alcohol from BDH; 1,4-dibromobutane, and 1,4-butanediol from 
Merck. The synthesis of the dendritic host, DAB-dendr-(NHCONH-Ad) 64 , $\mathbf{1}$, was previously desribed by Baars et al. ${ }^{1}$
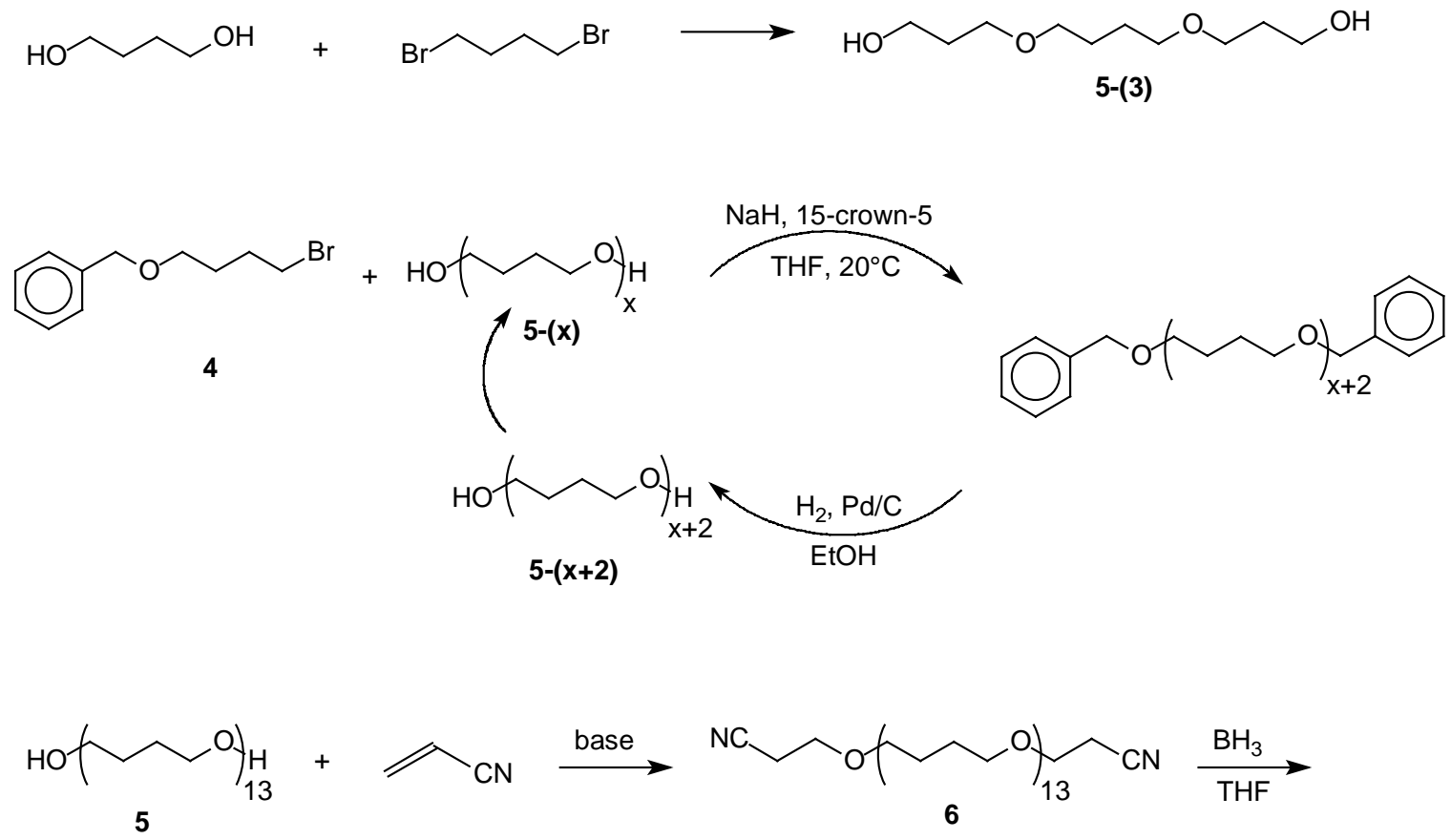<smiles>CCOC(=O)C[N+](=O)[O-]</smiles><smiles>CCOC(=O)CNC(=O)NCCCOC(C)(C)CCCOC(C)(C)CCCNC(=O)NCC(=O)OCC</smiles><smiles>CC(C)(CCCOCCCNC(=O)NCC(=O)O)OCCCNC(=O)NCC(=O)O</smiles>

Benzyl 4-bromobutyl ether, 4. Sodium hydroxide (100 g, $2.5 \mathrm{~mol})$ was slowly dissolved in water (400 ml) and cooled to $20^{\circ} \mathrm{C}$. Benzyl alcohol (107.5 g, $\left.1.00 \mathrm{~mol}\right), 1,4$-dibromobutane (500 g, $\left.2.3 \mathrm{~mol}\right)$ and tetrabutylammonium hydrogensulfate $(8.5 \mathrm{~g}, 25 \mathrm{mmol})$ were added, and the reaction mixture was stirred at $70^{\circ} \mathrm{C}$ for $4 \mathrm{~h}$. Water $(500 \mathrm{ml})$ was added and the product was extracted with hexane $(500 \mathrm{ml})$. The organic layer was dried with magnesium sulfate, filtered, and concentrated. The excess of dibromobutane was recovered by distillation $\left(29^{\circ} \mathrm{C} / 0.35 \mathrm{mbar}\right)$. The product was distilled two times $\left(72^{\circ} \mathrm{C} / 1.5^{*} 10^{-2} \mathrm{mbar}\right)$ and obtained as a colourless liquid $(209 \mathrm{~g}, 86 \%)$. The product is stored under 
argon, in the dark at $4{ }^{\circ} \mathrm{C}$ to prevent it from oxidation. ${ }^{1} \mathrm{H}-\mathrm{NMR}\left(\mathrm{CDCl}_{3}\right): \delta$ 7.4-7.2 $(\mathrm{m}, 5 \mathrm{H}, \mathrm{Ph}-\underline{\mathrm{H}}), 4.50$ (s, $2 \mathrm{H}, \mathrm{PhCH}_{2}$ ), 3.50 (tr, $\left.2 \mathrm{H}, \mathrm{OC}_{2} \mathrm{CH}_{2}, \mathrm{~J}=6.2 \mathrm{~Hz}\right), 3.43$ (tr, $\left.2 \mathrm{H}, \mathrm{BrCl}_{2}, \mathrm{~J}=6.6 \mathrm{~Hz}\right), 1.97(\mathrm{~m}, 2 \mathrm{H}$, $\left.\mathrm{OCH}_{2} \mathrm{CH}_{2}\right), 1.76$ (m, 2H, $\left.\mathrm{BrCH}_{2} \mathrm{CH}_{2}\right) .{ }^{13} \mathrm{C}-\mathrm{NMR}\left(\mathrm{CDCl}_{3}, 100 \mathrm{MHz}\right): \delta$ 138.4, 72.9, 69.2, 33.7, 29.6, 29.3. FT-IR (ATR): $v$ 2856, 1496, 1454, 1360, 1248, 1101, 733, $696 \mathrm{~cm}^{-1}$. GC-MS: $\mathrm{t}_{\mathrm{r}}=4.27 \mathrm{~min},<1 \%$ 1,4-dibromobutane, $<1 \%$ benzyl bromide.

5,10-Dioxa-tetradecane-1,14-diol, oligo(THF) 3-mer, 5-(3). Sodium (5.75 g, 0.25 mol) was cut in small pieces, washed with heptane $(100 \mathrm{ml})$, and reacted under dissolution in 1,4-butanediol (45.0 g, $0.50 \mathrm{~mol})$ at $70^{\circ} \mathrm{C}$ while stirring vigorously. The reaction mixture was heated to $100^{\circ} \mathrm{C}$ and $1,4-$ dibromobutane ( $21.6 \mathrm{~g}, 0.10 \mathrm{~mol}$ ) was added dropwise. The mixture was stirred from $3 \mathrm{~h}$, after which it was cooled to room temperature. Water $(40 \mathrm{ml})$ was added, and the aqueous layer was extracted four times with dichloromethane $(70 \mathrm{ml})$. The combined organic layers were extracted one more time with water $(20 \mathrm{ml})$, and was then dried with magnesium sulfate, and concentrated in vacuo. The yellow product was dissolved in ether $(250 \mathrm{ml})$, and recrystallized at $-18^{\circ} \mathrm{C}$ overnight. The ether was decanted, the product washed with cold ether $(100 \mathrm{ml})$, and redissolved in ether $(100 \mathrm{ml})$. The ether was evaporated in vacuo on a rotary evaporator without putting the flask in the water bath. This allowed the product to precipitate during drying, and yielded a fine, white powder $(7.02 \mathrm{~g}, 30 \%) . \mathrm{T}_{\mathrm{m}}=36^{\circ} \mathrm{C}$ (Lit: $\left.33^{\circ} \mathrm{C}\right)$. GC-MS: $\mathrm{t}_{\mathrm{r}}=5.08 \mathrm{~min},>98 \%$ pure. ${ }^{1} \mathrm{H}-\mathrm{NMR}\left(\mathrm{CDCl}_{3}\right): \delta 3.64\left(\mathrm{q}, 4 \mathrm{H}, \mathrm{CH}_{2} \mathrm{OH}, \mathrm{J}=5.9 \mathrm{~Hz}\right), 3.46(\mathrm{t}$, 8H. $\left.\underline{\mathrm{C}}_{2} \mathrm{OC} \underline{H}_{2}, \mathrm{~J}=5.9 \mathrm{~Hz}\right), 2.62(\mathrm{t}, 2 \mathrm{H}, \mathrm{OH}, \mathrm{J}=5.9 \mathrm{~Hz}), 1.68\left(\mathrm{~m}, 12 \mathrm{H}, \mathrm{OCH}_{2} \underline{\mathrm{C}}_{2} \mathrm{C}_{2} \mathrm{CH}_{2} \mathrm{O}\right) .{ }^{13} \mathrm{C}-\mathrm{NMR}$

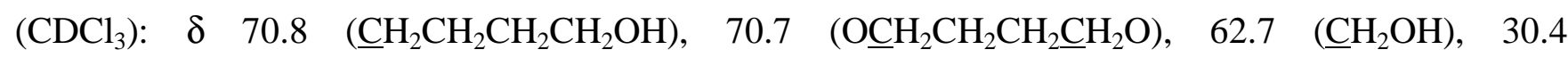
$\left(\underline{\mathrm{CH}_{2}} \mathrm{CH}_{2} \mathrm{OH}\right), 26.9\left(\underline{\mathrm{CH}}_{2} \mathrm{CH}_{2} \mathrm{CH}_{2} \mathrm{OH}\right), 26.3\left(\mathrm{OCH}_{2} \underline{\mathrm{CH}_{2}} \underline{\mathrm{CH}}_{2} \mathrm{CH}_{2} \mathrm{O}\right)$. Anal. Calcd. (\%) for $\mathrm{C}_{12} \mathrm{H}_{26} \mathrm{O}_{4}: \mathrm{C}$ 61.51, H 11.18. Found (\%): C 61.31, H 11.33. FT-IR (ATR): 3361, 2937, 2859, 1446, 1370, 1105, $1057 \mathrm{~cm}^{-1}$. MALDI-TOF $\left[\mathrm{M}+\mathrm{Na}^{+}\right]=$Calcd. 257.2 Da. Obsd. 256.8 Da. 
oligo(THF), 5-(x). The synthesis of oligo(THF) 5-mer, 5-(5) is given as a typical example. NaH (15.93 g 60\% disp., $0.40 \mathrm{~mol})$ was washed two times with pentane $(100 \mathrm{ml})$, and decanted carefully. THF (200 ml) was added to this, and the suspension was cooled on an ice bath. Diol, 5-(3), (11.70 g, $0.050 \mathrm{~mol})$ was dissolved in THF $(50 \mathrm{ml})$, and added dropwise to the suspension. Be careful: hydrogen gas evolution! After this, 15-crown-5 (4.40 g, $0.020 \mathrm{~mol})$ was added. The suspension was stirred at room temperature for 30 min under an argon atmosphere. Subsequently, benzyl 4-bromobutyl ether, 2, (48.60 g, $0.20 \mathrm{~mol})$ was added dropwise. The reaction mixture was stirred for $4 \mathrm{~h}$ at room temperature. After the reaction was complete, the reaction mixture was cooled on an ice bath, and water (20 ml) was added slowly. Be careful: hydrogen gas evolution! When evolution of gas ceased, the reaction mixture was evaporated to dryness, and sodium hydroxide solution (100 $\mathrm{ml} 1 \mathrm{M})$ was added, and this was extracted two times with ether $(200 \mathrm{ml})$. The combined organic layers were concentrated, and redissolved in ethanol $(100 \mathrm{ml})$. Water $(2 \mathrm{ml})$, sulfuric acid $(0.5 \mathrm{~g})$, and palladium $(0.1 \mathrm{~g} 10 \%$ on carbon) were added to this. The reaction mixture was flushed with nitrogen. Subsequently, it was hydrogenated at 65 psi and room temperature in a Parr reactor for several hours, until the pressure no longer dropped. The reaction mixture was flushed with nitrogen, filtered, neutralized with sodium hydroxide solution and concentrated. Then it was poured in sodium hydroxide solution (70 $\mathrm{ml} 1 \mathrm{M})$ and stirred for $15 \mathrm{~min}$, after which it was extracted three times with ether $(100 \mathrm{ml})$. The combined ether layers were dried with sodium sulfate, filtered, and ether was evaporated under reduced pressure. The residue was recrystallized from ether $(80 \mathrm{ml})$ at $-18^{\circ} \mathrm{C}$. The white powder was filtered off, washed with cold ether and dried in vacuo $(14.87 \mathrm{~g}, 78 \%)$. $\mathrm{T}_{\mathrm{m}}=41^{\circ} \mathrm{C}\left(\mathrm{Lit}: 39^{\circ} \mathrm{C}\right)$. GC-MS: $\mathrm{t}_{\mathrm{r}}=7.2 \mathrm{~min},>98 \%$ pure. ${ }^{1} \mathrm{H}-\mathrm{NMR}\left(\mathrm{CDCl}_{3}\right): \delta 3.63\left(\mathrm{q}, 4 \mathrm{H}, \mathrm{CH}_{2} \mathrm{OH}, \mathrm{J}=5.9 \mathrm{~Hz}\right), 3.47-3.40\left(\mathrm{~m}, 16 \mathrm{H} . \mathrm{CH}_{2} \mathrm{OCH}_{2}\right), 2.62(\mathrm{t}, 2 \mathrm{H}, \mathrm{OH}$, $\mathrm{J}=5.7 \mathrm{~Hz}), 1.69-1.62\left(\mathrm{~m}, 20 \mathrm{H}, \mathrm{OCH}_{2} \mathrm{CH}_{2} \mathrm{CH}_{2} \mathrm{CH}_{2} \mathrm{O}\right) .{ }^{13} \mathrm{C}-\mathrm{NMR}\left(\mathrm{CDCl}_{3}\right): \delta 70.8,70.6,70.5,62.7$, 30.4, 26.9, 26.5, 26.4, 26.4. Anal. Calcd. (\%) for $\mathrm{C}_{20} \mathrm{H}_{42} \mathrm{O}_{6}: \mathrm{C}$ 63.46, H 11.18. Found (\%): C 63.14, $\mathrm{H}$ 11.39. MALDI-TOF $\left[\mathrm{M}+\mathrm{Na}^{+}\right]=$Calcd. 401.3 Da. Obsd. 401.0 Da. 
oligo(THF) 7-mer, 5-(7). Yield: $24.5 \mathrm{~g}(74 \%) . \mathrm{T}_{\mathrm{m}}=36^{\circ} \mathrm{C}\left(\mathrm{Lit}: 36^{\circ} \mathrm{C}\right) .{ }^{1} \mathrm{H}-\mathrm{NMR}\left(\mathrm{CDCl}_{3}\right): \delta 3.64(\mathrm{q}$, $\left.4 \mathrm{H}, \underline{\mathrm{C}}_{2} \mathrm{OH}, \mathrm{J}=5.4 \mathrm{~Hz}\right), 3.47-3.42\left(\mathrm{~m}, 24 \mathrm{H} . \mathrm{C}_{2} \mathrm{OC}_{2}\right), 2.56$ (t, 2H, O, $\left.\mathrm{J}=5.6 \mathrm{~Hz}\right), 1.70-1.62(\mathrm{~m}$, $28 \mathrm{H}, \mathrm{OCH}_{2} \mathrm{CH}_{2} \mathrm{CH}_{2} \mathrm{CH}_{2} \mathrm{O}$ ). Anal. Calcd. (\%) for $\mathrm{C}_{28} \mathrm{H}_{58} \mathrm{O}_{8}: \mathrm{C}$ 64.33, H 11.18. Found (\%): $\mathrm{C}$ 64.11, H 11.27. MALDI-TOF $\left[\mathrm{M}+\mathrm{Na}^{+}\right]=$Calcd. 545.4 Da. Obsd. 545.2, 473.2 Da.

oligo(THF) 9-mer, 5-(9). Yield: $29.35 \mathrm{~g}(78 \%) . \mathrm{T}_{\mathrm{m}}=31^{\circ} \mathrm{C} .{ }^{1} \mathrm{H}-\mathrm{NMR}\left(\mathrm{CDCl}_{3}\right): \delta 3.64(\mathrm{q}, 4 \mathrm{H}$, $\left.\mathrm{C}_{2} \mathrm{OH}, \mathrm{J}=5.9 \mathrm{~Hz}\right), 3.48-3.41\left(\mathrm{~m}, 32 \mathrm{H} . \mathrm{C}_{2} \mathrm{OCH}_{2}\right), 2.51(\mathrm{t}, 2 \mathrm{H}, \mathrm{OH}), 1.69-1.60(\mathrm{~m}, 36 \mathrm{H}$, $\left.\mathrm{OCH}_{2} \mathrm{CH}_{2} \underline{\mathrm{C}}_{2} \mathrm{CH}_{2} \mathrm{O}\right) .{ }^{13} \mathrm{C}-\mathrm{NMR}\left(\mathrm{CDCl}_{3}\right): \delta 70.8,70.6,70.5,62.7,30.4,26.9,26.5,26.4,26.4$. Anal. Calcd. (\%) for $\mathrm{C}_{36} \mathrm{H}_{74} \mathrm{O}_{10}$ : C 64.83, H 11.18. Found (\%): C 64.47, H 11.18. MALDI-TOF [M+Na $\left.{ }^{+}\right]=$ Calcd. 689.5 Da. Obsd. 689.4, 617.3 Da.

oligo(THF) 11-mer, 5-(11). Yield: $21.9 \mathrm{~g}(61 \%) . \mathrm{T}_{\mathrm{m}}=32^{\circ} \mathrm{C} .{ }^{1} \mathrm{H}-\mathrm{NMR}\left(\mathrm{CDCl}_{3}\right): \delta 3.64\left(4 \mathrm{H}, \mathrm{C}_{2} \mathrm{OH}\right)$, 3.47-3.40 (40H. $\left.\mathrm{C}_{2} \underline{\mathrm{OCH}}_{2}\right), 2.52(2 \mathrm{H}, \mathrm{OH}), 1.67-1.62\left(44 \mathrm{H}, \quad \mathrm{OCH}_{2} \mathrm{CH}_{2} \underline{\mathrm{CH}}_{2} \mathrm{CH}_{2} \mathrm{O}\right) .{ }^{13} \mathrm{C}-\mathrm{NMR}$ $\left(\mathrm{CDCl}_{3}\right): \delta 70.8,70.6,70.5,62.7,30.3,26.9,26.5$. Anal. Calcd. (\%) for $\mathrm{C}_{44} \mathrm{H}_{90} \mathrm{O}_{12}: \mathrm{C} 65.15, \mathrm{H} 11.18$. Found (\%): C 65.27, H 11.16. MALDI-TOF $\left[\mathrm{M}+\mathrm{Na}^{+}\right]=$Calcd. 833.6 Da. Obsd. 833.4, 761.3, 689.2 Da.

oligo(THF) 13-mer, 5-(13). Yield: $20.0 \mathrm{~g}(77 \%) . \mathrm{T}_{\mathrm{m}}=31{ }^{\circ} \mathrm{C} .{ }^{1} \mathrm{H}-\mathrm{NMR}\left(\mathrm{CDCl}_{3}\right): \delta 3.63(\mathrm{q}, 4 \mathrm{H}$, $\left.\mathrm{C}_{2} \mathrm{OH}, \mathrm{J}=5.9 \mathrm{~Hz}\right), 3.47-3.40$ (m, 46H. $\left.\underline{\mathrm{C}}_{2} \mathrm{OC}_{2}\right), 2.61$ (t, $\left.2 \mathrm{H}, \mathrm{O} \underline{\mathrm{H}}, \mathrm{J}=5.7 \mathrm{~Hz}\right), 1.70-1.60(\mathrm{~m}, 50 \mathrm{H}$, $\left.\mathrm{OCH}_{2} \mathrm{CH}_{2} \mathrm{CH}_{2} \mathrm{CH}_{2} \mathrm{O}\right) .{ }^{13} \mathrm{C}-\mathrm{NMR}\left(\mathrm{CDCl}_{3}\right): \delta$ 70.8, 70.6, 70.5, 62.6, 30.3, 26.9, 26.5, 26.4, 26.4. Anal. Calcd. (\%) for $\mathrm{C}_{52} \mathrm{H}_{106} \mathrm{O}_{14}: \mathrm{C}$ 65.37, $\mathrm{H}$ 11.18. Found (\%): C 65.18, $\mathrm{H}$ 11.35. MALDI-TOF $\left[\mathrm{M}+\mathrm{Na}^{+}\right]=$ Calcd. 977.8 Da. Obsd. 977.8, 905.7, 833.6, 761.5 Da. 


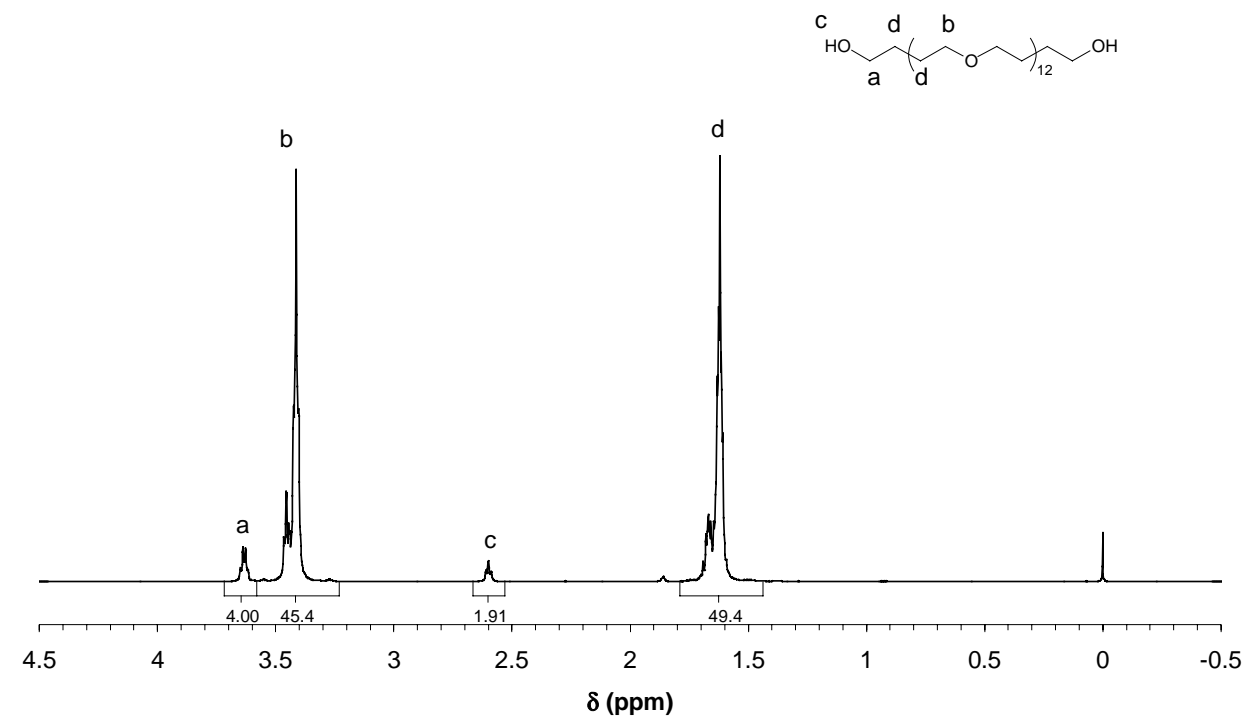

Figure: ${ }^{1} \mathrm{H}-\mathrm{NMR}$ spectrum of oligo(THF) 13-mer, 5-(13).

Bis(2-cyanoethyl)-oligo(THF) 13-mer, 6. Oligo(THF) 13-mer diol, 5-(13), (0.95 g; 1.00 mmol) and 15-crown-5 (4.4 mg; $0.02 \mathrm{mmol})$ were dissolved in acrylonitrile $(4 \mathrm{ml})$ and cooled on an icebath. Sodium hydride $(0.8 \mathrm{mg} 60 \%$ dispersion in mineral oil; $0.02 \mathrm{mmol})$ is added to the solution, and the reaction mixture is stirred at $0^{\circ} \mathrm{C}$ for about $15 \mathrm{~min}$, after which the reaction mixture turned slightly yellow. At this point, the reaction was quenched by addition of a drop of concentrated hydrochloric acid. The solution was concentrated, the residue taken up in dichloromethane $(10 \mathrm{ml})$ and centrifuged at $4500 \mathrm{rpm}$. The mixture was decanted, filtered, and concentrated in vacuo. The product was obtained as a slightly yellow, viscous liquid, that slowly crystallized $(1.01 \mathrm{~g}, 96 \%) .{ }^{1} \mathrm{H}-\mathrm{NMR}\left(\mathrm{CDCl}_{3}\right): \delta 3.62(\mathrm{t}$, 4H, $\mathrm{OC}_{2} \mathrm{CH}_{2} \mathrm{CN}$ ), 3.51 (t, $4 \mathrm{H}, \underline{\mathrm{C}}_{2} \mathrm{OCH}_{2} \mathrm{CH}_{2} \mathrm{CN}$ ), 3.40 (br. t, $48 \mathrm{H}, \mathrm{OC}_{2} \mathrm{CH}_{2} \mathrm{CH}_{2} \underline{\mathrm{C}}_{2} \mathrm{O}$ main chain), 2.59 (t, $4 \mathrm{H}, \mathrm{C}_{2} \mathrm{CN}$ ), 1.60 (br. m, 52H, $\mathrm{OCH}_{2} \underline{\mathrm{CH}}_{2} \mathrm{CH}_{2} \mathrm{CH}_{2} \mathrm{O}$ main chain). ${ }^{13} \mathrm{C}-\mathrm{NMR}\left(\mathrm{CDCl}_{3}\right): \delta 117.7$ (N), $71.0\left(\underline{\mathrm{CH}}_{2} \mathrm{OCH}_{2} \mathrm{CH}_{2} \mathrm{CN}\right), 70.4\left(\mathrm{OCH}_{2} \mathrm{CH}_{2} \mathrm{CH}_{2} \mathrm{CH}_{2} \mathrm{O}\right.$ main chain), $65.1\left(\mathrm{OCH}_{2} \mathrm{CH}_{2} \mathrm{CN}\right), 26.3$ $\left(\mathrm{OCH}_{2} \underline{\mathrm{CH}}_{2} \mathrm{CH}_{2} \mathrm{CH}_{2} \mathrm{O}\right.$ main chain), $18.7\left(\underline{\mathrm{CH}}_{2} \mathrm{CN}\right) . \mathrm{FT}-\mathrm{IR}(\mathrm{ATR}): v 2939,2855,2161 （ \mathrm{w}, \mathrm{C} \equiv \mathrm{N}$ stretching), 1367, 1103 (C-O stretching) $\mathrm{cm}^{-1}$. 
Bis-(3-aminopropyl)-oligo(THF) 13-mer, 7. To a solution of borane-tetrahydrofuran complex (8 ml $1 \mathrm{M}$ in THF, $8.0 \mathrm{mmol})$ in dry THF $(25 \mathrm{ml})$ was added slowly $6(1.01 \mathrm{~g}, 0.96 \mathrm{mmol})$ dissolved in dry $\operatorname{THF}(15 \mathrm{ml})$ at $0^{\circ} \mathrm{C}$. The solution was stirred for $30 \mathrm{~min}$ at $0^{\circ} \mathrm{C}$, after which it was heated to reflux for 4 h. The reaction mixture was cooled to $0^{\circ} \mathrm{C}$, and methanol $(8 \mathrm{ml})$ was added dropwise. (Be careful: hydrogen-gas evolution). Hydrochloric acid ( $0.4 \mathrm{ml}, 37 \%$ in water) was added slowly, and the reaction mixture was stirred for $1 \mathrm{~h}$, and subsequently evaporated to dryness under reduced pressure. Trimethyl borate was removed by three coevaporations with methanol (3 times $10 \mathrm{ml}$ ). To the viscous liquid was added sodium hydroxide solution $(15 \mathrm{ml}, 1 \mathrm{M}$ in water), and this was extracted with diethyl ether (3 times $30 \mathrm{ml}$ ). The combined organic layers were dried with sodium sulfate, filtered, and the solvent was evaporated on a rotary evaporator without putting the flask in the waterbath. During the evaporation, the product precipitated from the cold solution and was obtained as a white powder $(0.94 \mathrm{~g}, 93 \%)$. ${ }^{1} \mathrm{H}-$ NMR $\left(\mathrm{CDCl}_{3}\right): \delta 3.49\left(\mathrm{t}, 4 \mathrm{H}, \mathrm{OC}_{2} \mathrm{CH}_{2} \mathrm{CH}_{2} \mathrm{NH}_{2}, \mathrm{~J}=6.2\right), 3.41\left(\mathrm{~m}, 52 \mathrm{H}, \mathrm{OCH}_{2} \mathrm{CH}_{2} \mathrm{CH}_{2} \mathrm{CH}_{2} \mathrm{O}\right), 2.79(\mathrm{t}$, $\left.4 \mathrm{H}, \underline{\mathrm{CH}}_{2} \mathrm{NH}_{2}, \mathrm{~J}=7.6\right), 1.71$ (t, $\left.4 \mathrm{H}, \mathrm{OCH}_{2} \underline{\mathrm{CH}}_{2} \mathrm{CH}_{2} \mathrm{NH}_{2}, \mathrm{~J}=6.6\right), 1.62\left(\mathrm{~m}, 52 \mathrm{H}, \mathrm{OCH}_{2} \underline{\mathrm{CH}}_{2} \mathrm{C}_{2} \mathrm{CH}_{2} \mathrm{O}\right), 1.12$ $\left(\mathrm{s}, 4 \mathrm{H}, \mathrm{NH}_{2}\right) .{ }^{13} \mathrm{C}-\mathrm{NMR}\left(\mathrm{CDCl}_{3}\right): \delta 70.6\left(\mathrm{OCH}_{2} \mathrm{CH}_{2} \mathrm{CH}_{2} \mathrm{CH}_{2} \mathrm{O}\right), 68.9\left(\mathrm{OCH}_{2} \mathrm{CH}_{2} \mathrm{CH}_{2} \mathrm{NH}_{2}\right), 39.7$ $\left(\underline{\mathrm{CH}_{2}} \mathrm{NH}_{2}\right), 33.6\left(\mathrm{OCH}_{2} \mathrm{CH}_{2} \mathrm{CH}_{2} \mathrm{NH}_{2}\right), 26.5\left(\mathrm{OCH}_{2} \underline{\mathrm{CH}}_{2} \underline{\mathrm{CH}}_{2} \mathrm{CH}_{2} \mathrm{O}\right)$. FT-IR (ATR): v 3361, 2942, 2863 , $1492,1371,1106,995 \mathrm{~cm}^{-1}$.

Bis[3-(carboxymethylureido)propyl]-oligo(THF) 13-mer, 2. Bis(3-aminopropyl)-oligo(THF) 13mer, 7, (2.00 g, $1.82 \mathrm{mmol})$ was dissolved in chloroform $(40 \mathrm{ml})$ and ethyl isocyanatoacetate $(0.47 \mathrm{~g}$, $3.64 \mathrm{mmol}$ ) was added. The reaction mixture was stirred at room temperature for $30 \mathrm{~min}$, and subsequently evaporated to dryness. The product was redissolved in THF $(20 \mathrm{ml})$ and sodium hydroxide solution (20 ml $1 \mathrm{M}$ ) was added. The reaction mixture was stirred for 2 days, after which it was slightly acidified by addition of concentrated hydrochloric acid solution (approx. $2 \mathrm{ml}$ ), and concentrated in vacuo. The aqueous layer was extracted with dichloromethane (three times $25 \mathrm{ml}$ ), and the organic layers were combined, dried with sodium sulfate, and evaporated to dryness. The product was obtained 


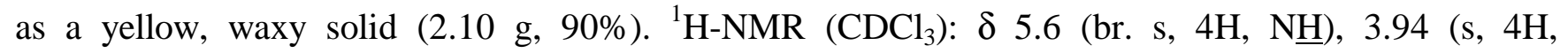
$\left.\mathrm{CH}_{2} \mathrm{COOH}\right), 3.51$ (t, 4H, OC $\left.\underline{\mathrm{H}}_{2} \mathrm{CH}_{2} \mathrm{CH}_{2} \mathrm{NH}\right), 3.41$ (m, 52H, $\left.\mathrm{CH}_{2} \underline{\mathrm{CH}}_{2} \mathrm{O}\right), 3.28$ (t, 4H, $\left.\mathrm{CH}_{2} \mathrm{CH}_{2} \mathrm{NH}\right), 1.76$ (m, 4H, $\mathrm{OCH}_{2} \underline{\mathrm{CH}}_{2} \mathrm{CH}_{2} \mathrm{NH}$ ), 1.62 (m, 52H, $\mathrm{OCH}_{2} \mathrm{CH}_{2}$ ). FT-IR (ATR): v 3359 (N-H stretching), 2939, $2855,1733(\mathrm{COOH}), 1638(\mathrm{C}=\mathrm{O}$ urea $), 1568,1368,1103 \mathrm{~cm}^{-1}$.

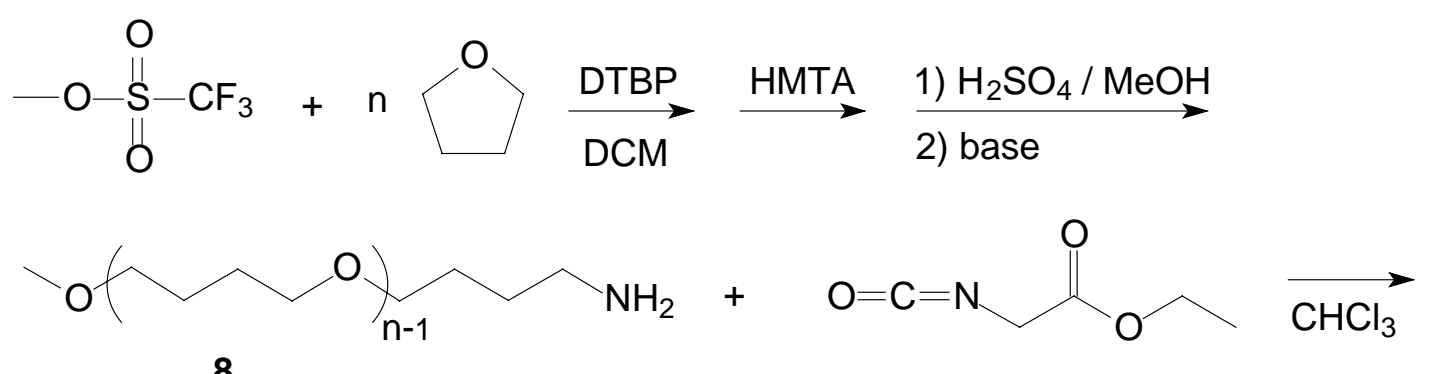

8
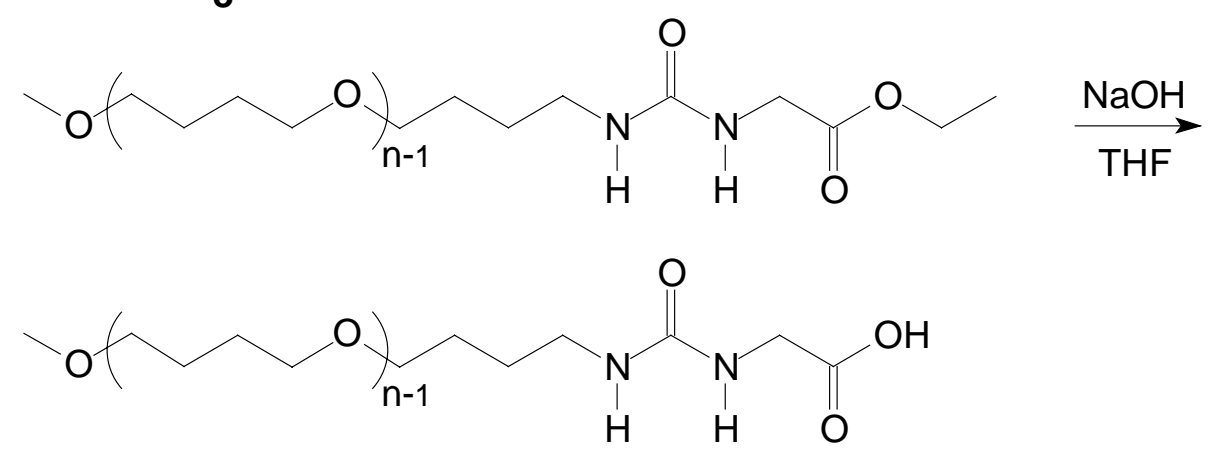

3

$\alpha$-(4-Aminobutyl)- $\omega$-methyl-oligo(THF), 8. Freshly distilled THF (10.0 ml, $0.123 \mathrm{~mol})$ was inserted into a dried $50 \mathrm{ml}$ flask via a syringe under exclusion of air, and 2,6-di-tert-butylpyridine (0.75 ml, 3.35 mmol) was added to this. The solution was cooled to $0^{\circ} \mathrm{C}$ and kept under an argon atmosphere. Methyl trifluoromethanesulfonate $(1.00 \mathrm{~g}, 6.09 \mathrm{mmol})$ was dissolved in dichloromethane $(10 \mathrm{ml})$, and added to the previous solution. The reaction mixture was stirred for $50 \mathrm{~min}$ at $0^{\circ} \mathrm{C}$ under an argon atmosphere. The reaction was quenched by addition of hexamethylene tetraamine $(2.14 \mathrm{~g}, 15.3 \mathrm{mmol})$ dissolved in chloroform $(100 \mathrm{ml})$. The turbid reaction mixture was allowed to warm to room temperature. Subsequently, it was evaporated to dryness under reduced pressure, and the residue was redissolved in methanol $(60 \mathrm{ml})$ and toluene $(40 \mathrm{ml})$, and sulfuric acid $(3 \mathrm{ml})$ was added. The reaction mixture was heated to $100^{\circ} \mathrm{C}$ for $3 \mathrm{~h}$, and after cooling down, it was neutralized by addition of concentrated sodium 
hydroxide solution (approx. $3 \mathrm{ml} 10 \mathrm{M}$ ). The salts were filtered off, and the filtrate was evaporated to dryness under reduced pressure, redissolved in THF $(10 \mathrm{ml})$, and precipitated in cold, diluted sodium hydroxide solution $(100 \mathrm{ml} 0.1 \mathrm{M})$. The white precipitate was filtered off, washed, and redissolved in diethyl ether $(50 \mathrm{ml})$. The solution was dried with sodium sulfate and then evaporated to dryness under reduced pressure while cooling the flask on an ice bath, allowing a white powder to crystallize (2.28 g). ${ }^{1} \mathrm{H}-\mathrm{NMR}\left(\mathrm{CDCl}_{3}, 400 \mathrm{MHz}\right): \delta 3.41\left(\mathrm{~m}, 62 \mathrm{H}, \mathrm{CH}_{2} \mathrm{CH}_{2} \mathrm{O}\right), 3.33\left(\mathrm{~s}, 3 \mathrm{H}, \mathrm{C}_{3}\right), 2.71\left(\mathrm{t}, 2 \mathrm{H}, \mathrm{C}_{2} \mathrm{NH}_{2}\right.$, $\mathrm{J}=5.5 \mathrm{~Hz}), 1.62\left(\mathrm{~m}, 62 \mathrm{H}, \mathrm{OCH}_{2} \mathrm{CH}_{2}\right), 1.50\left(\mathrm{~m}, 2 \mathrm{H}, \mathrm{CH}_{2} \mathrm{CH}_{2} \mathrm{NH}_{2}\right) .{ }^{13} \mathrm{C}-\mathrm{NMR}\left(\mathrm{CDCl}_{3}, 100 \mathrm{MHz}\right): 72.6$ $\left(\mathrm{CH}_{3} \mathrm{OCH}_{2}\right), 70.5\left(\mathrm{CH}_{2} \underline{\left.\mathrm{CH}_{2} \mathrm{O}\right),} 58.5\left(\underline{\mathrm{CH}}_{3} \mathrm{O}\right), 42.1\left(\underline{\mathrm{CH}}_{2} \mathrm{NH}_{2}\right), 30.6\left(\underline{\mathrm{CH}}_{2} \mathrm{CH}_{2} \mathrm{NH}_{2}\right), 26.5\left(\mathrm{OCH}_{2} \underline{\mathrm{CH}}_{2}\right)\right.$. $\mathrm{M}_{\mathrm{n}}\left({ }^{1} \mathrm{H}-\mathrm{NMR}\right)=1150 \mathrm{~g} / \mathrm{mol}$.

$\alpha$-[4-(Carboxymethylureido)butyl]- $\omega$-methyl-oligo(THF), 3. $\alpha$-Amino- $\omega$-methoxy-oligo(THF), 8 , $(0.50 \mathrm{~g}, 0.43 \mathrm{mmol})$ was dissolved in chloroform $(10 \mathrm{ml})$ and ethyl isocyanatoacetate $(61.8 \mathrm{mg}, 0.48$ mmol) was added. The reaction mixture was stirred at room temperature for $30 \mathrm{~min}$, and subsequently evaporated to dryness. The product was redissolved in THF (15 ml) and sodium hydroxide solution (15 ml $1 \mathrm{M}$ ) was added. The reaction mixture was stirred overnight, after which it was slightly acidified by addition of concentrated hydrochloric acid solution (approx. $1.5 \mathrm{ml}$ ), and concentrated in vacuo. The aqueous layer was extracted with dichloromethane (three times $20 \mathrm{ml}$ ), and the organic layers were combined, dried with sodium sulfate, and evaporated to dryness. The product was obtained as a pale, waxy solid $(0.47 \mathrm{~g}, 66 \%) .{ }^{1} \mathrm{H}-\mathrm{NMR}\left(\mathrm{CDCl}_{3}\right): \delta 5.32$ (br. s, $\left.1 \mathrm{H}, \mathrm{NH}\right), 5.18$ (br. s, $\left.1 \mathrm{H}, \mathrm{NH}\right), 3.95(\mathrm{~s}, 2 \mathrm{H}$, $\left.\mathrm{CH}_{2} \mathrm{COOH}\right), 3.41\left(\mathrm{~m}, 84 \mathrm{H}, \mathrm{CH}_{2} \underline{\mathrm{CH}}_{2} \mathrm{O}\right), 3.33\left(\mathrm{~s}, 3 \mathrm{H}, \underline{\mathrm{CH}}_{3}\right), 3.22\left(\mathrm{~m}, 2 \mathrm{H}, \mathrm{CH}_{2} \underline{\mathrm{C}}_{2} \mathrm{NH}\right), 1.62(\mathrm{~m}, 84 \mathrm{H}$, $\mathrm{OCH}_{2} \underline{\mathrm{CH}}_{2}$ ), 1.43 (m, 2H, $\left.\underline{\mathrm{C}}_{2} \mathrm{CH}_{2} \mathrm{NH}\right)$. FT-IR (ATR): v 3331 (N-H stretching), 2938, 2853, 1751 $(\mathrm{COOH}), 1647(\mathrm{C}=\mathrm{O}$ urea $), 1563,1447,1369,1105 \mathrm{~cm}^{-1} \cdot \mathrm{M}_{\mathrm{n}}\left({ }^{1} \mathrm{H}-\mathrm{NMR}\right)=1650 \mathrm{~g} / \mathrm{mol}$.

Preparation of the reversible network. The dendritic host, DAB-dendr-(NHCONH-Ad) $64, \mathbf{1},(0.238$ $\left.\mathrm{g}, 1.29 * 10^{-5} \mathrm{~mol}\right)$ was dissolved in chloroform $(2 \mathrm{ml})$, and added to a solution of $2\left(0.262 \mathrm{~g}, 2.06^{*} 10^{-4}\right.$ 
mol) in chloroform $(2 \mathrm{ml})$. The volume of the solution was filled to $5.00 \mathrm{ml}$ to obtain a $100 \mathrm{~g} / \mathrm{l}$ solution of the complex. The viscous solution was thoroughly mixed by mechanical stirring and/or sonication. FT-IR: $v 3356(\mathrm{~N}-\mathrm{H}$ stretching $), 1630(\mathrm{C}=\mathrm{O}$ urea $), 1522 \mathrm{~cm}^{-1}$.

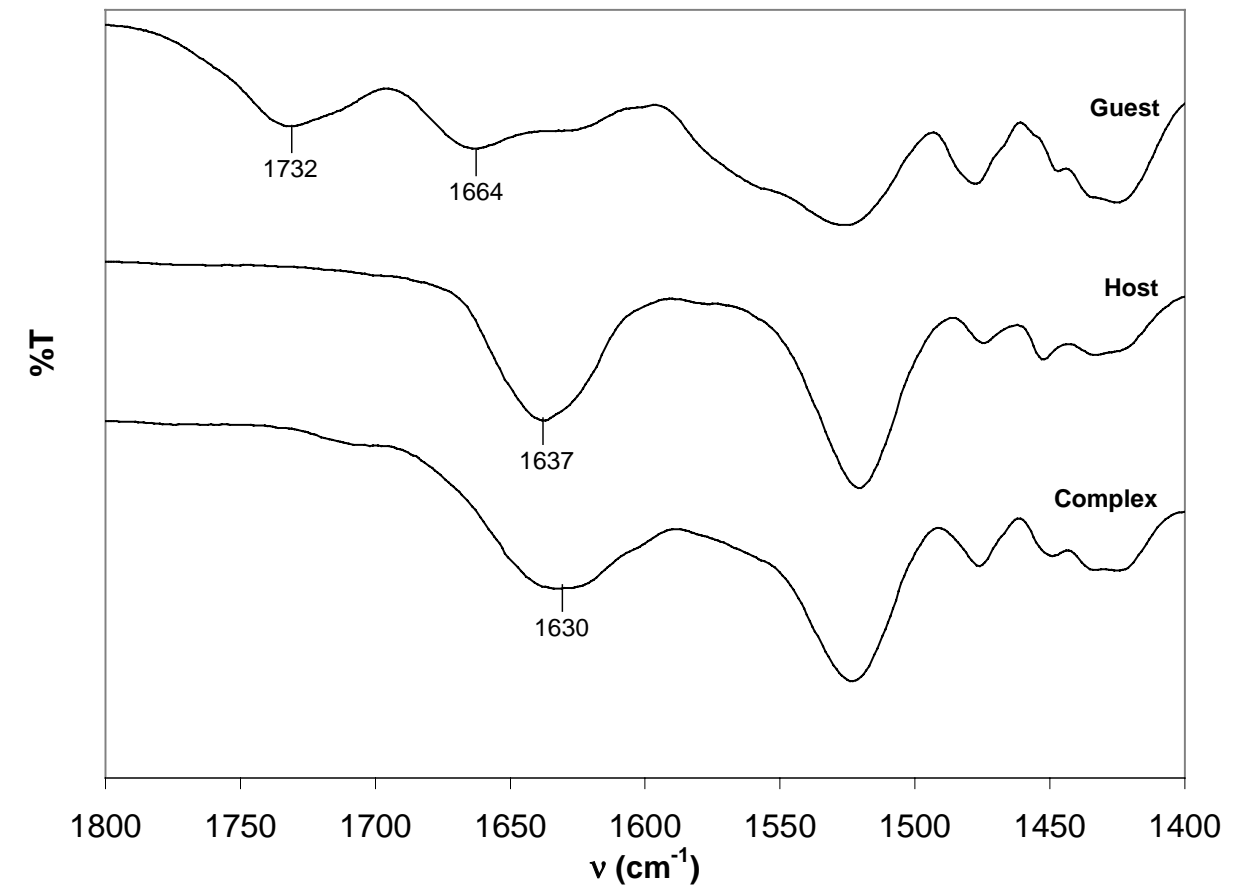

Figure: FT-IR spectra of solutions of bifunctional guest 2, host 1, and their complex in $\mathrm{CDCl}_{3}$.

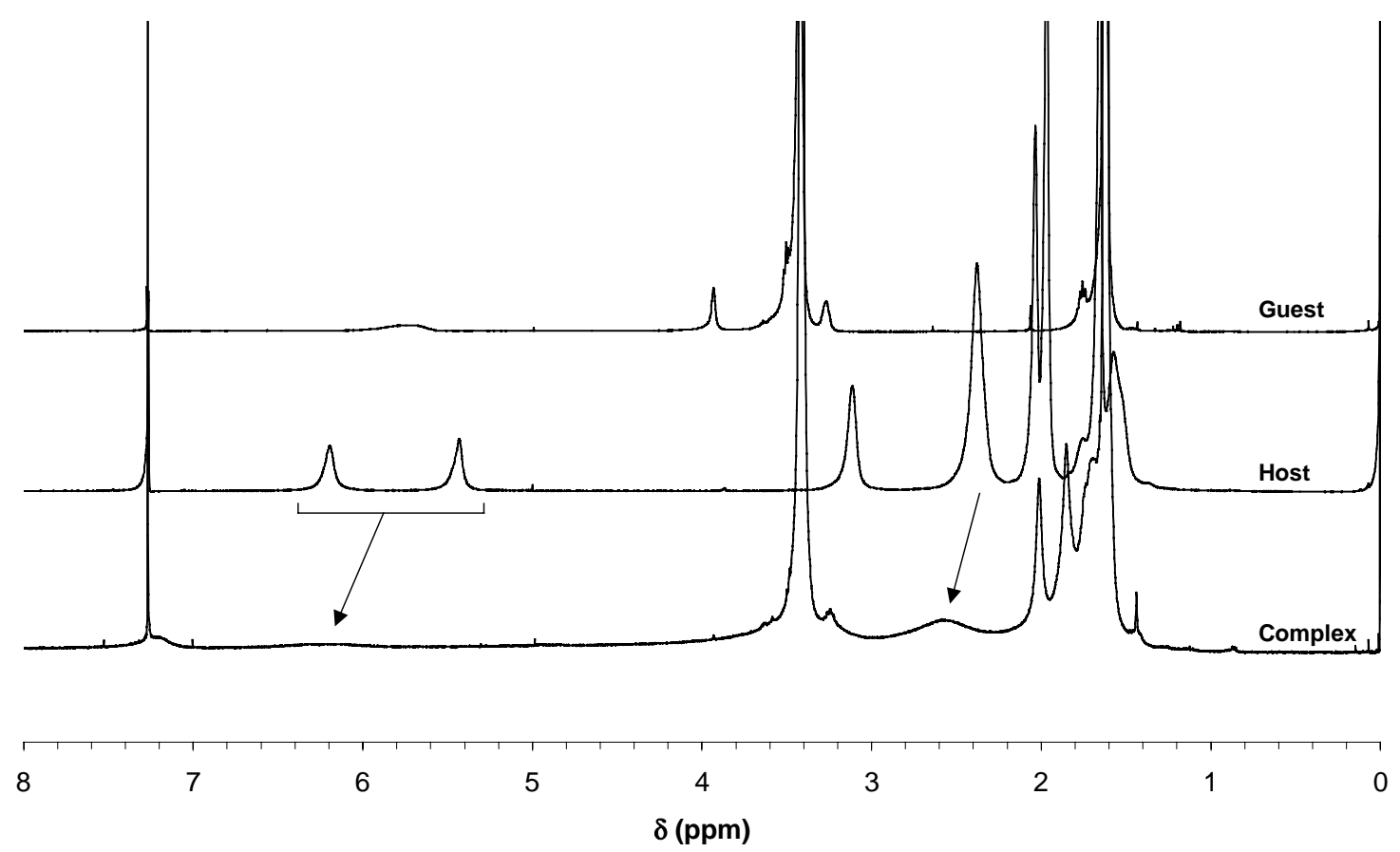

Figure: ${ }^{1} \mathrm{H}-\mathrm{NMR}$ spectra of solutions of bifunctional guest $\mathbf{2}$, host $\mathbf{1}$, and their complex in $\mathrm{CDCl}_{3}$. 
${ }^{1}$ Baars, M.W.P.L., Karlsson, A.J., Sorokin, V., De Waal, B.F.W., Meijer, E.W. Supramolecular modification of the periphery of dendrimers resulting in rigidity and functionality. Angew. Chem. Int. Ed. 39, 4262-4265 (2000). 